\title{
A simple spectrophotometric method for the determination of trace level lead in biological samples in the presence of aqueous micellar solutions
}

\author{
Humaira Khan $^{\mathrm{a}}$, M. Jamaluddin Ahmed ${ }^{\mathrm{b}, *}$ and M. Iqbal Bhanger ${ }^{\mathrm{a}}$ \\ ${ }^{a}$ National Centre of Excellence in Analytical Chemistry, University of Sindh, Jamshoro, Pakistan \\ ${ }^{\mathrm{b}}$ Laboratory of Analytical Chemistry, Department of Chemistry, University of Chittagong, Chittagong \\ 4331, Bangladesh
}

\begin{abstract}
A very simple, ultra-sensitive and fairly selective new spectrophotometric method has been developed for the rapid determination of lead(II) at ultra-trace level using 1,5-diphenylthiocarbazone (dithizone) in presence of aqueous micellar solutions. The proposed method enabled the determination of lead down to $\mu \mathrm{gl}^{-1}$ in human blood and urine in aqueous media without resource of any "clean-up" step. The most remarkable point of this method is that the presence of micellar system avoids the previous steps of solvent extraction and reduces the cost, toxicity while enhancing the sensitivity, selectivity and the molar absorptivity. The complex formation of lead in blood with dithizone was completed within a minute at room temperature and the absorbance remains stable for $24 \mathrm{~h}$. The average molar absorption coefficient and Sandell's sensitivity were found to be $3.99 \times 10^{5} 1 \mathrm{~mol}^{-1} \mathrm{~cm}^{-1}$ and $30 \mathrm{ng} \mathrm{cm}^{-2}$ of $\mathrm{Pb}$, respectively. Linear calibration graphs were obtained for $0.06-60 \mathrm{mg} \mathrm{l}^{-1}$ of $\mathrm{Pb}^{\mathrm{II}}$; the stoichiometric composition of the chelate is $1: 2$ (Pb:dithizone). The interference from over 60 cations, anions and complexing agents has been studied at $1 \mathrm{mgl}^{-1}$ of $\mathrm{Pb}^{\mathrm{II}}$. The method was successfully used in the determination of lead in several biological samples (human blood and urine and bovine liver), solution containing both lead(II) and lead(IV) and complex synthetic mixtures. The results of biological analyses by the spectrophotometric method were in excellent agreement with those obtained by AAS. The results of lead concentration in biological samples were varied with age, sex and place which have been discussed.
\end{abstract}

Keywords: Non-extractive spectrophotometry, lead determination, micellar media, dithizone, biological samples

\section{Introduction}

Lead in trace amounts is important industrially [1], as a: toxicant [2], biological nutrient [3], environmental pollutant [4] and occupational hazard [5], Lead is a serious cumulative body poison [6]. It enters our body systems through air, water, and food. The toxicity of lead has been studied extensively [2]. Inorganic lead $\left(\mathrm{Pb}^{2+}\right)$ binds itself with the - $\mathrm{SH}$ group in enzyme or proteins and acts as an enzyme inhibitor. Lead interferes with the calcium metabolism and gets deposited in the bone. Organic lead compounds, such as tetramethyl lead, are highly poisonous because they are absorbed readily by the body

\footnotetext{
${ }^{*}$ Corresponding author: Professor M. Jamaluddin Ahmed, Department of Chemistry, University of Chittagong, Chittagong 4331, Bangladesh. Fax: +880 31 726310; E-mail: mjahmed_bd@yahoo.com.
} 
through skin and mucus membrane. Acute lead poisoning in humans causes severe damage in the kidneys, liver, brain, reproductive system, and central nervous system, and some times causes death. Mild lead poisoning causes anemia, headache, and sore muscles and victim may feel fatigued and irritable. All these findings cause great concern regarding public health, demanding accurate determination of this metal ion at trace and sub-trace levels in biological samples.

1, 5-Diphenylthiocarbazone (dithizone) is one of the most widely used photometric reagents and forms colored water - insoluble complexes with a larger number of metal ions [7]. Metal-dithizone complexes are water insoluble and thus their determination requires a prior solvent extraction step into chloroform or carbon tetrachloride [8] followed by spectrophotometric measurements. Since these methods involve solvent extractions are lengthy and time-consuming and lack selectivity due to much interference [9]. Carbon tetrachloride and chloroform have already been listed as carcinogens by the EPA [10]. This problem has been overcome in recent years by introducing a hydrophobic micellar system generated by a surfactant similar to that employed in phase-transfer reactions [11]. Miceller systems are convenient to use because they are optically transparent, readily available, and relatively non-toxic and stable [12]. Nevertheless, the addition of surfactants at concentrations above the CMC to an aqueous medium to form a micellar solution is the most commonly preferred procedure today in Analytical Chemistry. The micelles altered the previous extraction procedure providing by a new reaction medium in which reaction rates, equilibrium constant, products formed, spectral parameters and some times stereochemistry could be altered. As a result, the introduction of a given reagent into altered environment can afford many beneficial changes that could eventually be advantageous to enhance the performance of the analytical method [13].

The aim of the present study is to develop a simpler direct spectrophotometer method for the trace determination of lead in human fluids with dithizone in the presence of inexpensive cationic micelles, such as cetyltrimethylammonium bromide (CTAB) in aqueous solutions. This method does not require a solvent-extraction step; hence, the use of carcinogenic carbon tetrachloride or chloroform is avoided. The method described here has recorded for the first time the non-extractive direct spectrophotometric determination of lead (II) in biological samples in aqueous media without the recourse of any "cleanup" step. This method is far more selective, non-extractive, simple and rapid than all of the existing spectrophotometric methods [14-21]. The method is based on the reaction of slightly absorbent dithizone in acidic solution with lead(II) to produce highly absorbent violet-chelate product, followed by the direct measurement of the absorbance in aqueous solution. With suitable masking, the reaction can be made highly selective.

\section{Experimental}

\subsection{Apparatus}

A. Perkin Elmer (Germany) (Model: Lambda-2) double-beam UV/VIS spectrophotometer and a WTW inolab (Germany) (Model: Level-1) pH-meter with a combination of electrodes were used for measurements of the absorbance and $\mathrm{pH}$, respectively. A Hitachi Ltd., Model 180-50, S.N.5721-2 Atomic Absorption Spectrophotometer with a deuterium lamp back ground corrector, equipped with graphite furnace GA-3, with lead hollow cathode lamps of Hitachi, and a Hitachi Model 056 recorder was used for comparison of the results. The experimental conditions were: slit width, $1.3 \mathrm{~nm}$; lamp current, $7.5 \mathrm{~mA}$; wavelength, $283.3 \mathrm{~nm}$; cuvette, cup; carrier gas, $200 \mathrm{ml} \mathrm{min}^{-1}$; sample volume, $10 \mu \mathrm{l}$. 


\subsection{Sample collection and preservation}

Human fluids (blood and urine) were collected from affected persons of Liaquat University of Medical and Health Science Hospital, Hyderabad and Agha Khan Hospital, Karachi; samples of normal persons were collected from Dadu District and Hyderabad City. Blood venous sample taken out with a polyethylene or polystyrene syringe is collected in polyethylene bottle of $5 \mathrm{ml}$ containing $\mathrm{Na}_{2}$-EDTA as anticoagulant, immediately after collection, they were stored in a salt-ice mixture and later, at laboratory, were kept $-20^{\circ} \mathrm{C}$.

\subsection{Reagents and solutions}

All chemicals used were of analytical reagent grade or the highest purity available. Doubly distilled de-ionized water, which is non-absorbent under ultraviolet radiation, was used throughout. Glass vassals were cleaned by soaking in acidified solutions of $\mathrm{KMnO}_{4}$ or $\mathrm{K}_{2} \mathrm{Cr}_{2} \mathrm{O}_{7}$, followed by washing with concentrated $\mathrm{HNO}_{3}$ and rinsed several times with de-ionized water. More rigorous contamination control was used when one lead levels in the specimens were low.

Cetyltrimethylammonium bromide (CTAB) solution $0.3 \mathrm{M}$. A $500 \mathrm{ml}$ of CTAB solution was prepared by dissolving $54.67 \mathrm{~g}$ of pure cetyltrimethylammonium bromide (E. Merck, Darmstadt, Germany) in 250-300 $\mathrm{ml}$ if doubly distilled de-ionized water, sonicated for $30 \mathrm{~min}$ and diluted up to the mark with de-ionized water when it became transparent.

1,5-Diphenylthiocarbazone (Dithizone) $1.95 \times 10^{-4} \mathrm{M}$. Prepared by dissolving the requisite amount $(0.005 \%)$ of diphenylthiocarbazone (Merck, Darmstadt) in a known volume of 2-propanol (Fluka, Germany). More dilute solutions of the reagent were prepared as required.

Lead(II) standard solutions $\left(4.83 \times 10^{-3} \mathrm{M}\right)$. A $100 \mathrm{ml}$ stock solution $\left(1 \mathrm{mg} \mathrm{ml}^{-1}\right)$ of divalent lead was prepared by dissolving $159.9 \mathrm{mg}$ of lead nitrate (E. Merck, Germany) in de-ionized water. Aliquots of this solution were standardized with EDTA using xylenol orange as an indicator. More dilute standard solutions were prepared from this stock solution, as and when required.

Lead(IV) stock solutions $\left(4.83 \times 10^{-3} \mathrm{M}\right)$. A $100 \mathrm{ml}$ of lead(IV) stock solution $\left(1 \mathrm{mg} \mathrm{ml}^{-1}\right)$ was prepared by dissolving $110.3 \mathrm{mg}$ of purified-grade lead(IV) oxide (The British Drug Houses LTD England) in de-ionized water containing 1-2 $\mathrm{ml}$ of 50\% hydrochloric acid. The lead tetrachloride $\left(\mathrm{PbCl}_{4}\right)$ solution in stable at room temperature $\left(25 \pm 5^{\circ} \mathrm{C}\right)$. The working standard of lead(IV) was prepared by appropriate dilution of this solution.

Sodium azide solution. A $2.5 \%(\mathrm{w} / \mathrm{v})$ sodium azide solution (E. Merck, Germany) was prepared by dissolving the requisite amount in de-ionized water.

Tartrate solution. A $100 \mathrm{ml}$ stock solution of tartrate $(0.1 \% \mathrm{w} / \mathrm{v})$ was prepared by dissolving $100 \mathrm{mg}$ of potassium sodium tartrate tetrahydrate (E. Merck, Darmstadt) in $(100 \mathrm{ml})$ de-ionized water.

Aqueous ammonia solution. A $100 \mathrm{ml}$ solution of aqueous ammonia was prepared by diluting $10 \mathrm{ml}$ of concentrated $\mathrm{NH}_{3}(28-30 \%)$ ACS grade to $100 \mathrm{ml}$ with de-ionized water. The solution was stored in a polypropylene bottle.

Other solutions. Solutions of a large number of inorganic ions and complexing agents were prepared from their AnalaR grade, or equivalent grade, water-soluble salts. In the case of insoluble substances, a special dissolution method was adopted [22]. 


\subsection{Procedure}

A series of standard solutions of a neutral aqueous solution containing 0.6-600 $\mu \mathrm{g}$ of lead (II) in a $10 \mathrm{ml}$ calibrated flask was mixed with 75-130 fold molar excess of a dithizone solution (preferably $1.5 \mathrm{ml}$ of $1.95 \times 10^{-4} \mathrm{M}$ ) and $0.3-2.0 \mathrm{ml}$ (preferably $1.0 \mathrm{ml}$ ) of $4 \times 10^{-3} \mathrm{M} \mathrm{HCl}$ followed by the addition 3-6 ml (preferably $4 \mathrm{ml}$ ) of $0.3 \mathrm{M} \mathrm{CTAB}$. The mixture was diluted to the mark with de-ionized water. The absorbance was measured at $500 \mathrm{~nm}$ against a corresponding reagent blank. The lead content in an unknown sample was determined using a concurrently prepared calibration graph.

\section{Results and discussion}

\subsection{Optimization of analytical parameters}

Absorption spectra. The absorption spectra of the lead (II)-dithizone system in a $4 \times 10^{-3} \mathrm{M}$ hydrochloric acid medium were recorded using a spectrophotometer. The absorption spectra of the lead(II)dithizone is a symmetric curve with the maximum absorbance at $500 \mathrm{~nm}$ and an average molar absorption coefficient of $3.99 \times 10^{5} 1 \mathrm{~mol}^{-1} \mathrm{~cm}^{-1}$ (Fig. 1). The reagent blank exhibited negligible absorbance at same wavelength $(500 \mathrm{~nm})$. In all instances, measurements were made at $500 \mathrm{~nm}$ against a reagent blank. The reaction mechanism of the present method is as reported earlier [23].

Effect of surfactant. Of the various surfactants [nonionic\{polyoxyethylenedodecylether (Brij-35), polyoxyethylene sorbitan monopalmitate (Tween-40), polyoxyethylene sorbitan mono-oleate (Tween80), TritonX-100\}; cationic \{cetyltrimethylammonium bromide (CTAB)\}; and anionic \{cetyl pyridinum chloride (CPC), sodium dodecyl sulfate (SDS) \}] studied, CTAB was found to be the best surfactant for the system. In a $0.3 \mathrm{M}$ CTAB medium, however, the maximum absorbance was observed; hence, a $0.3 \mathrm{M}$ CTAB solution was used in the determination procedure.

Different volumes of $0.3 \mathrm{M} \mathrm{CTAB}$ were added to a fixed metal ion concentration, and the absorbance was measured according to the standard procedure. It was observed that at $5 \mathrm{mg} \mathrm{l}^{-1} \mathrm{~Pb}$-chelate metal, 3-6 $\mathrm{ml}$ of $0.3 \mathrm{M} \mathrm{CTAB}$ produced a constant absorbance of the $\mathrm{Pb}$-chelate. Outside this range of surfactant the absorbance decreased (Fig. 2). For all subsequent measurements, $4 \mathrm{ml}$ of $0.3 \mathrm{M} \mathrm{CTAB}$ was added.

Effect of acidity. Of the various acids (nitric, sulfuric, hydrochloric and phosphoric) studied, hydrochloric acid was found to be the best acid for the system. The absorbance was at a maximum and constant when a $10 \mathrm{ml}$ of solution $\left(5 \mathrm{mg} \mathrm{l}^{-1}\right.$ ) contained $0.3-2 \mathrm{ml}$ of $4 \times 10^{-3} \mathrm{M}$ hydrochloric acid (or $\mathrm{pH}$ 3.66-2.87) at room temperature $\left(25 \pm 5^{\circ} \mathrm{C}\right)$. Outside this range of acidity, the absorbance decreased (Fig. 3). For all subsequent measurements, $1 \mathrm{ml}$ of $4 \times 10^{-3} \mathrm{M}$ hydrochloric acid (or $\mathrm{pH}$ 3.19) was added.

Effect of time. The reaction is very fast. Constant maximum absorbance was obtained just after dilution to volume, and remained strictly unaltered for $24 \mathrm{~h}$.

Effect of temperature. The absorbance at different temperatures, $0-50^{\circ} \mathrm{C}$, of a $10 \mathrm{ml}$ solution $\left(5 \mathrm{mg}{ }^{-1}\right)$ was measured according to the standard procedure. The absorbance was found to be strictly unaltered throughout the temperature range of $5-40^{\circ} \mathrm{C}$. Therefore, all measurements were performed at room temperature $\left(25 \pm 5^{\circ} \mathrm{C}\right)$. 


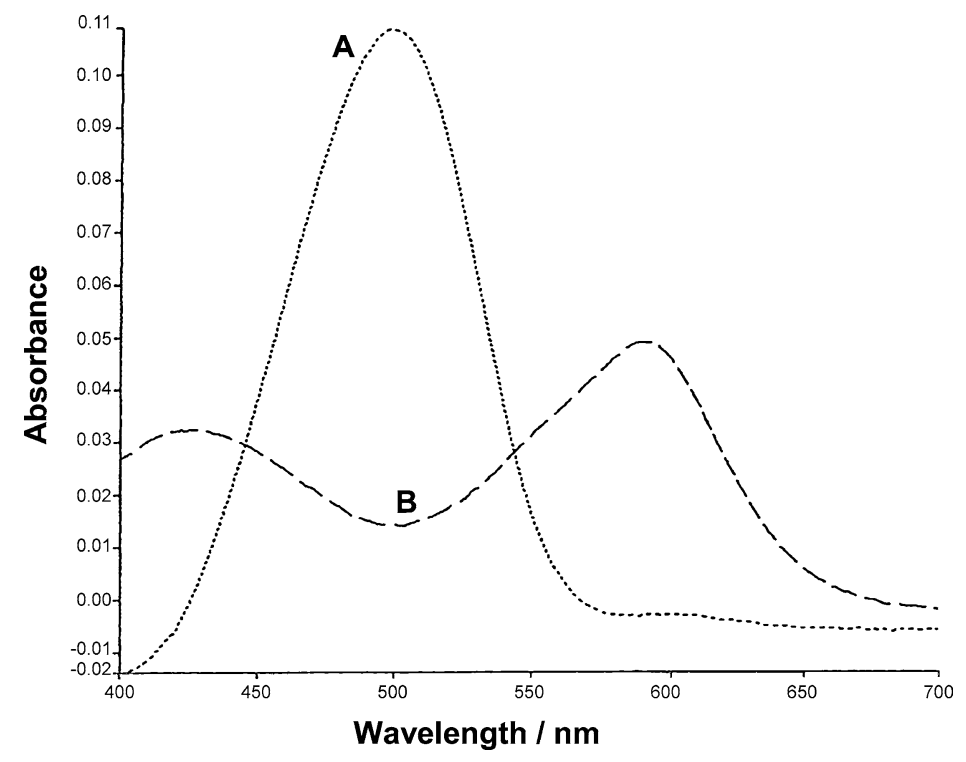

Fig. 1. A and B absorption spectra of $\mathrm{Pb}(\mathrm{II})$-dithizone system and reagent blank $\left(\lambda_{\max }=500 \mathrm{~nm}\right)$ in cationic micellar media of cetyltrimethylammonium bromide.

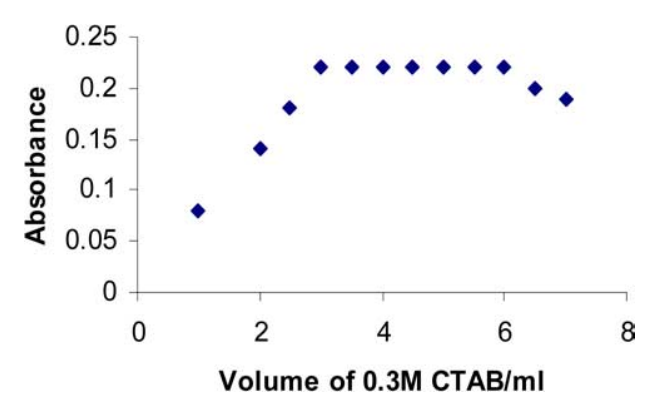

Fig. 2. Effect of a surfactant on the absorbance of the $\mathrm{Pb}(\mathrm{II})$-dithizone system.

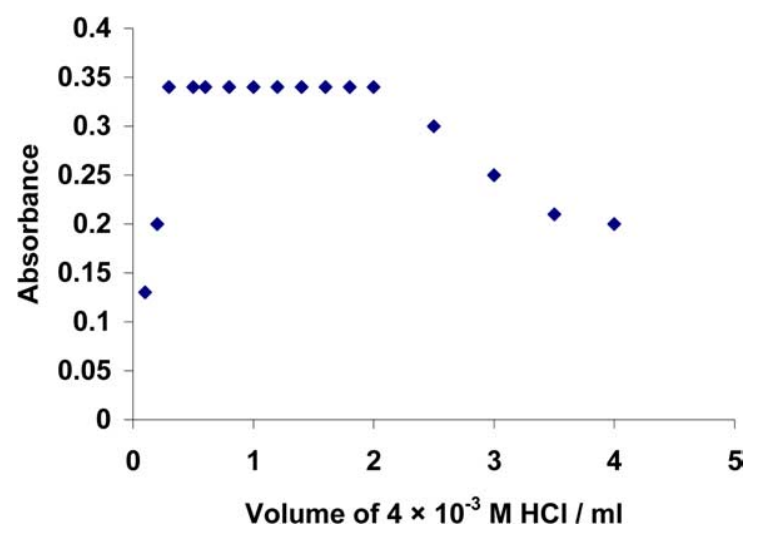

Fig. 3. Effect of the acidity on the absorbance of the $\mathrm{Pb}(\mathrm{II})$-dithizone system. 


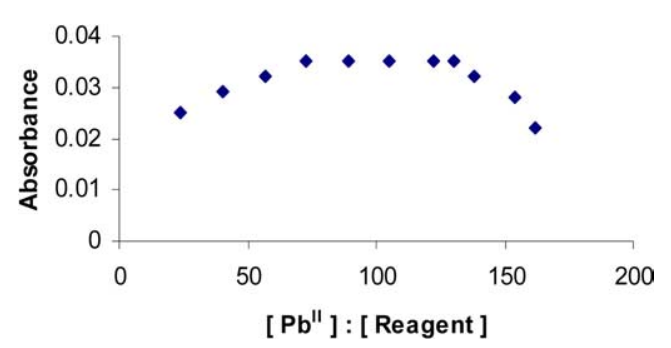

Fig. 4. Effect of a reagent [Dithizone : $\mathrm{Pb}^{\mathrm{II}}$ molar concentration ratio] on the absorbance of the $\mathrm{Pb}$ (II)-dithizone system.

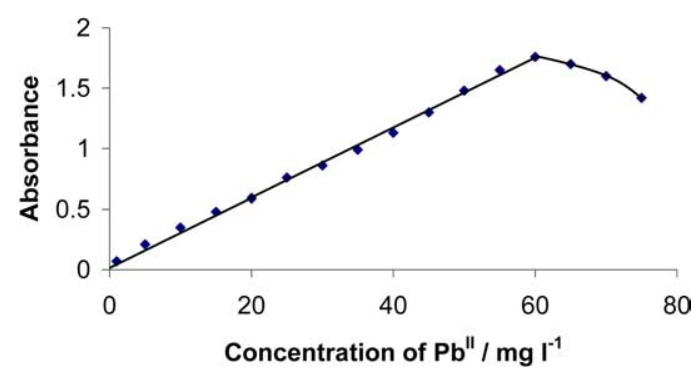

Fig. 5. Calibration graph: C, $1-60 \mathrm{mg}^{-1}$ of $\mathrm{Pb}^{\mathrm{II}}$.

Effect of the reagent concentration. Different molar excesses of dithizone were added to a fixed metalion concentration, and the absorbances were measured according to the standard procedure. It was observed that at $0.5 \mathrm{mg}^{-1} \mathrm{~Pb}$ metal: reagent molar ratios 1:75 and 1:130 produced a constant absorbance of the $\mathrm{Pb}$-chelate (Fig. 4). The effect of reagent at different concentration of $\mathrm{Pb}^{\mathrm{II}}\left(5 \mathrm{mg} \mathrm{l}^{-1}\right)$ was also studied but similar effect was observed. For all subsequent measurements, $1.5 \mathrm{ml}$ of $1.95 \times 10^{-4} \mathrm{M}$ dithizone reagent was added.

Calibration graph (Beer's law and sensitivity). The effect of metal concentration was studied over 0.01-100 $\mathrm{mg}^{-1}$, distributed in four different sets $\left(0.01-0.1,0.1-1,1-10,10-100 \mathrm{mg} \mathrm{l}^{-1}\right)$ for convenience of the measurement. The absorbance was linear for $0.06-60 \mathrm{mgl}^{-1}$ of lead at $500 \mathrm{~nm}$. From the slope of the calibration graph, the average molar absorption coefficient was found to be $3.99 \times 10^{5}$ $1 \mathrm{~mol}^{-1} \mathrm{~cm}^{-1}$. The Sandell's sensitivity [24] (concentration for 0.001 absorbance unit) was found to be $30 \mathrm{ng} \mathrm{cm}^{-2}$. Of the three calibration graphs, the one showing the limit of the linearity range is given in Fig. 5; the next two were straight-line graphs passing through the origin $\left(R^{2}=0.9947\right)$. The selected analytical parameters obtained with the optimization experiments are summarized in Table 1.

\subsection{Validation of the method}

Effect of foreign ions. The effect of over 50 cations, anions and complexing agents on the determination of only $1 \mathrm{mg} \mathrm{l}^{-1}$ of $\mathrm{Pb}^{\mathrm{II}}$ was studied. The criterion for interference [25] was an absorbance value varying by more than $5 \%$ from the expected value for $\mathrm{Pb}^{\mathrm{II}}$ alone. There was no interference from the following 1000 fold amount of tartrate or thiocyanide; a 500-fold amount of fluoride, azide or ammonium(I); a 300fold amount of acetate, ascorbic acid or bromide. Tartrate or thiocyanide prevented the interference of equal fold amounts of $\mathrm{Hg}^{\mathrm{II}}$ and 10 -fold amounts of $\mathrm{Cd}, \mathrm{Zn}, \mathrm{Fe}$ (III) or $\mathrm{Co}$ (II). Interferences of five cations have been completely removed by using $\mathrm{CN}^{-}$as masking agent. Interferences of these five metal ions have also been effectively removed by short single step ion exchange separation process using Amberlite 
Table 1

Selected analytical parameters obtained with optimization experiments

\begin{tabular}{|c|c|c|}
\hline Parameter & Studied range & Selected value \\
\hline Wavelength $(\lambda / \mathrm{nm})$ & $200-800$ & 500 \\
\hline Acidity $(\mathrm{M} \mathrm{HCl})$ & $4 \times 10^{-5}-1.6 \times 10^{-3}$ & $\begin{array}{c}1.2 \times 10^{-4}-8 \times 10^{-4} \\
\left(\text { preferably } 4 \times 10^{-4} \mathrm{M}\right)\end{array}$ \\
\hline $\mathrm{pH}$ & $4.08-2.68$ & $\begin{array}{c}3.66-2.87 \\
\text { (preferably } 3.19)\end{array}$ \\
\hline $\begin{array}{l}\text { Surfactant (M cetyltrimethyl- } \\
\text { ammoniumbromide (CTAB) }\end{array}$ & $0-0.24$ & $\begin{array}{c}0.09-0.18 \\
\text { (preferably } 0.12 \text { ) }\end{array}$ \\
\hline Time (h) & $0-24$ & $\begin{array}{c}1 \mathrm{~min}-24 \mathrm{~h} \\
\text { (preferably } 5 \mathrm{~min})\end{array}$ \\
\hline Temperature $\left({ }^{\circ} \mathrm{C}\right)$ & $0-70$ & $\begin{array}{c}10-40 \\
(\text { preferably } 25 \pm 5 \text { ) }\end{array}$ \\
\hline Reagent (fold molar excess, M:R) & $1: 1-1: 200$ & $\begin{array}{c}1: 75-1: 130 \\
\text { (preferably } 1: 120 \text { ) }\end{array}$ \\
\hline Linear range $\left(\mathrm{mg} \mathrm{l}^{-1}\right)$ & $0.001-100$ & $0.06-60$ \\
\hline $\begin{array}{l}\text { Molar extinction coefficient } \\
\left(1 \mathrm{~mol}^{-1} \mathrm{~cm}^{-1}\right)\end{array}$ & $2.4 \times 10^{5}-6.0 \times 10^{5}$ & $3.99 \times 10^{5}$ \\
\hline Sandell's Sensitivity $\left(\mathrm{ng} \mathrm{cm}^{-2}\right.$ ) & $1-100$ & 30 \\
\hline Detection limit $\left(\mu \mathrm{gl}^{-1}\right)$ & $1-100$ & 10 \\
\hline Reproducibility (\% RSD) & $0-5$ & $0-2$ \\
\hline Regression coefficient & $0.9935-0.996$ & 0.9947 \\
\hline
\end{tabular}

$\mathrm{X}$ AD-8 resin (100-200 mesh) anion exchanger [26]. However, for those ions whose tolerance limit has been studied, their tolerance ratios are mentioned in Table 2 .

Composition of the absorbance. Job's method [27] of continuous variation and the molar-ratio [28] method were applied to ascertain the stoichiometric composition of the complex. A Pb-dithizone $(1: 2)$ complex was indicated by both methods.

Precision and accuracy. The precision of the present method was evaluated by determining different concentrations of lead (each analyzed at least five times). The relative standard deviation $(n=5)$ was $2-0 \%$ for $0.6-600 \mu \mathrm{g}$ of $\mathrm{Pb}^{\mathrm{II}}$ in $10 \mathrm{ml}$, indicating that this method is highly precise and reproducible. The detection limit [29] (3s of the blank) and Sandell's sensitivity [24] (concentration for 0.001 absorbance unit) for lead(II) were found to be $10 \mu \mathrm{gl}^{-1}$ and $30 \mathrm{ng} \mathrm{cm}^{-2}$, respectively. The results of the total lead in a number of real samples were in good agreement with the expected values (Table 4). The reliability of our $\mathrm{Pb}$-chelate procedure was tested by recovery studies. The method was also tested by analyzing several synthetic mixtures containing lead(II) and diverse ions (Table 3). The results of biological (human fluids) analyses by the spectrophotometric method were in excellent agreement with those obtained by AAS (Table 5). The results for the speciation of lead(II) and lead(IV) in mixtures were highly reproducible (Table 6). Hence, the precision and accuracy of the method were excellent.

Determination of lead in synthetic mixtures. Several synthetic mixtures of varying compositions containing lead(II) and diverse ions of known concentrations were determined by the present method using tartrate as a masking agent; and the results were found to be highly reproducible. The results are shown in Table 3. Accurate recoveries were achieved in all solutions. 
Table 2

Table of tolerance limits of foreign ions*, Tolerance ratio, [Species (x)]/Pb ${ }^{\mathrm{II}}(\mathrm{w} / \mathrm{w})$

\begin{tabular}{lclc}
\hline Species, $\mathrm{x}$ & $\begin{array}{c}\text { Tolerance ratio, } \\
\mathrm{x} / \mathrm{Pb}^{\mathrm{II}}\end{array}$ & Species, $\mathrm{x}$ & $\begin{array}{c}\text { Tolerance ratio, } \\
\mathrm{x} / \mathrm{Pb}^{\mathrm{II}}\end{array}$ \\
\hline Aluminium & $50^{\mathrm{d}}$ & Cobalt & $10^{\mathrm{a}}$ \\
Ammonium (I) & 100 & Calcium & 100 \\
Arsenic (III) & 100 & Chromium (III) & 100 \\
Arsenic (V) & 100 & Cesium & 100 \\
Ascorbic acid & 200 & Cerium (IV) & $100^{\mathrm{a}}$ \\
Azide & 500 & Indium (III) & $25^{\mathrm{a}}$ \\
Acetate & 300 & Manganese (II) & 100 \\
Bromide & 200 & Magnesium & 100 \\
Barium & 100 & Potassium & 100 \\
Beryllium & $50^{\mathrm{a}}$ & Copper & $20^{\mathrm{b}+\mathrm{c}}$ \\
Citrate & 100 & Palladium & 100 \\
Carbonate & 100 & Selenium (VI) & 100 \\
Chloride & 50 & Selenium (IV) & 100 \\
Fluoride & 1000 & Sodium & 100 \\
Iodide & 100 & Molybdenum (VI) & $50^{\mathrm{a}}$ \\
Nitrate & 100 & Nickel (II) & $10^{\mathrm{a}+\mathrm{b}}$ \\
Tartrate & 1000 & Tin (IV) & 100 \\
Phosphate & 100 & Vanadium (V) & $10^{\mathrm{b}}$ \\
Sulfate & 100 & Mercury (II) & $11^{\mathrm{a}+\mathrm{b}}$ \\
Sulfide & 100 & Iron (II) & $10^{\mathrm{a}+\mathrm{d}}$ \\
Thiocyanide & 1000 & Thallium (I) & 100 \\
Antimony & 100 & Tungsten (VI) & 100 \\
Bismuth (III) & 25 & Zinc & $10^{\mathrm{a}+\mathrm{b}}$ \\
Cadmium & $10^{\mathrm{a}+\mathrm{b}}$ & & \\
\hline Tolerance & & & \\
\hline
\end{tabular}

* Tolerance limit was defined as ratio that causes less than 5 percent interference.

${ }^{\mathrm{a}}$ With $10 \mathrm{mgl}^{-1}$ tartrate, ${ }^{\mathrm{b}}$ with $10 \mathrm{mg} \mathrm{l}^{-1}$ thiocyanide, ${ }^{\mathrm{c}}$ with $10 \mathrm{mg} \mathrm{l}^{-1}$ thiosulfate,

${ }^{\mathrm{d}}$ with $10 \mathrm{mgl}^{-1}$ fluoride.

Table 3

Determination of lead in some synthetic mixtures

\begin{tabular}{llccc}
\hline \multirow{2}{*}{ Sample } & Composition of mixtures $\left(\mathrm{mg} \mathrm{l}^{-1}\right)$ & \multicolumn{2}{c}{ Lead(II) $\left(\mathrm{mg} \mathrm{l}^{-1}\right)$} & \multirow{2}{*}{ Recovery $\pm \mathrm{s},(\%)$} \\
\cline { 3 - 4 } & & 0.50 & 0.49 & $98 \pm 0.5$ \\
$\mathrm{~A}$ & $\mathrm{~Pb}^{2+}$ & 1.00 & 1.00 & $100 \pm 0.0$ \\
& & 0.50 & 0.50 & $100 \pm 0.0$ \\
$\mathrm{~B}$ & $\mathrm{~A}$ & 1.00 & 0.98 & $98 \pm 0.5$ \\
& & 0.50 & 0.49 & $98 \pm 0.6$ \\
$\mathrm{C}$ & $\mathrm{As}$ in $\mathrm{A}+\mathrm{Ca}(20)+\mathrm{Na}(20)+\mathrm{K}(20)+$ Tartrate $(500)$ & 1.00 & 1.00 & $100 \pm 0.0$ \\
& & 0.50 & 0.52 & $104 \pm 1.2$ \\
$\mathrm{D}$ & $\mathrm{As}$ in $\mathrm{C}+\mathrm{Mg}(20)+\mathrm{Mn}^{2+}(20)+\mathrm{Sn}^{2+}(20)$ & 1.00 & 1.06 & $106 \pm 1.4$ \\
& & 0.50 & 0.54 & $108 \pm 1.8$ \\
$\mathrm{E}$ & $\mathrm{As}$ in $\mathrm{D}+\mathrm{Ba}(20)+\mathrm{Se}^{4+}(20)+\mathrm{As}^{3+}(20)+\mathrm{NO}_{3}^{-}(20)$ & 1.00 & 1.09 & $109 \pm 1.5$ \\
\hline
\end{tabular}

${ }^{*}$ Average of five analyses of each sample. 
Table 4

Determination of lead in certified reference materials

\begin{tabular}{lccc}
\hline $\begin{array}{l}\text { Certified reference material } \\
\text { (composition) }\end{array}$ & \multicolumn{2}{c}{ Lead (\%) } & $\begin{array}{c}\text { Recovery } \pm \mathrm{s}^{\mathrm{a}} \\
(\%)\end{array}$ \\
\cline { 2 - 3 } & $\begin{array}{c}\text { Certified } \\
\text { value }\end{array}$ & $\begin{array}{c}\text { Found } \\
(n=5)\end{array}$ & $99 \pm 1.0$ \\
\hline $\begin{array}{l}\text { BAS-5g, brass } \\
(\mathrm{Cu}, \mathrm{Zn}, \mathrm{Pb}, \mathrm{Sn}, \mathrm{Ni} \text { and } \mathrm{P})\end{array}$ & 2.23 & 2.21 & $104 \pm 0.5$ \\
$\begin{array}{l}\mathrm{BAS}-10 \mathrm{~g} ; \text { high-tensile brass } \\
(\mathrm{Cu}, \mathrm{Fe}, \mathrm{Pb}, \mathrm{Ni}, \mathrm{Sn}, \mathrm{Al}, \mathrm{Zn} \text { and Mn) }\end{array}$ & 0.23 & 0.24 & \\
NBS-1577, Bovine liver $\mu \mathrm{gg}^{-1}$ & $0.34 \pm 0.08$ & $0.33 \pm 0.07$ & $97.1 \pm 1.5$ \\
\hline
\end{tabular}

${ }^{\mathrm{a}}$ The measure of the precision is standard deviation, $\pm \mathrm{s}$.

Determination of lead in brass, alloys, steels and bovine liver (certified reference materials). A $0.1 \mathrm{~g}$ amount of a brass or alloys or steel sample containing $2.23-0.23 \%$ of lead was weighed accurately and placed in a 50-ml Erlenmeyer flask and digested following a method recommended by Parker et al. [30] in presence of oxidizing agent. The solution was then cooled and neutralized with a dilute $\mathrm{NH}_{4} \mathrm{OH}$ solution. The resulting solution was filtered, if necessary, through a Whatman No. 40 filter paper into a $25-\mathrm{ml}$ calibrated flask. The residue was washed with a small volume of hot water and the volume was made up to the mark with de-ionized water.

A suitable aliquot $(1-2 \mathrm{ml})$ of the above solution was taken into a 10-ml calibrated flask and lead content was determined as described under a procedure using tartrate or thiocyanide as masking agent. The proposed procedure for the spectrophotometric determination of lead was applied to the analyses of bovine liver (NBS-1577) $\mathrm{CRM}_{\mathrm{s}}$ obtained from the National Research Council of Canada using tartrate or thiocyanide as masking agent, following a method recommended by Sun et al. [31]. Based on five replicate analyses, the average lead concentration determination by the spectrophotometric method was in close agreement with the certified values (Table 4).

\subsection{Applications}

The present method was successfully applied to the determination of lead in a series of biological samples (human blood and urine) (Table 5), and also solution containing both lead(II) and lead(IV) in a mixture (Table 6). The results of biological analyses by the spectrophotometric method were found to be in excellent agreement with those obtained by AAS (Table 5).

Determination of lead in biological samples. Human blood $(5-10 \mathrm{ml})$ or urine (10-20 ml) was taken into a 100-ml micro-Kjeldahl flask. The sample was digested according to the method recommended by Mitra [32] in presence of oxidizing agent. The content of the flask was filtered and neutralized with dilute ammonia in presence of a $1-2 \mathrm{ml} 0.01 \%(\mathrm{w} / \mathrm{v})$ tartrate solution. The resultant solution was then transferred quantitatively into a $25-\mathrm{ml}$ calibrated flask and made up to the mark with de-ionized water.

A suitable aliquot $(1-2 \mathrm{ml})$ of the final solution was pipetted out into a 10-ml calibrated flask, and the lead content was determined as described under procedure using tartrate or thiocyanide as masking agent. The results of biological analyses by the spectrophotometric method were found to be excellent agreement with those obtained by AAS. The results are shown in Table 5.

Interpretation of results. The analytical results must be evaluated with regard to the validity of the analytical method. Poor analytical quality may lead to false conclusions [33]. Keeping this in our mind the 
Table 5

Concentration of lead in blood and urine samples

\begin{tabular}{|c|c|c|c|c|c|c|c|c|}
\hline \multirow[t]{3}{*}{ S. No: } & \multirow[t]{3}{*}{ Sample } & \multicolumn{4}{|c|}{ Lead $\left(\mu \mathrm{g} \mathrm{dl}^{-1}\right)$} & \multirow{3}{*}{$\begin{array}{l}\text { Collection } \\
\text { site }\end{array}$} & \multirow{3}{*}{$\begin{array}{l}\text { Sex } \\
(\text { age }+ \text { year })\end{array}$} & \multirow[t]{3}{*}{ Sample source } \\
\hline & & \multicolumn{2}{|c|}{ AAS $(n=5)$} & \multicolumn{2}{|c|}{ Proposed $(n=5)$} & & & \\
\hline & & Found & RDS, \% & Found & RDS, $\%$ & & & \\
\hline \multirow[t]{2}{*}{1} & Blood & 15.0 & 1.0 & 17.0 & 1.2 & Village & Female (5) & Normal child \\
\hline & Urine & 4.2 & 0.8 & 4.5 & 0.6 & & & \\
\hline \multirow[t]{2}{*}{2} & Blood & 21.5 & 1.2 & 20.6 & 1.3 & Village & Male (10) & Normal child \\
\hline & Urine & 5.3 & 0.7 & 4.8 & 0.8 & & & \\
\hline \multirow[t]{2}{*}{3} & Blood & 26.4 & 1.4 & 27.5 & 1.2 & City & Female (12) & Normal child \\
\hline & Urine & 6.2 & 0.5 & 5.9 & 0.7 & & & \\
\hline \multirow[t]{2}{*}{4} & Blood & 30.3 & 1.6 & 31.5 & 1.4 & City & Male (13) & Normal child \\
\hline & Urine & 7.5 & 1.0 & 7.8 & 0.8 & & & \\
\hline \multirow[t]{2}{*}{5} & Blood & 38.0 & 1.5 & 40.5 & 1.5 & City & Female (37) & Normal adult \\
\hline & Urine & 8.6 & 0.6 & 8.8 & 1.1 & & & \\
\hline \multirow[t]{2}{*}{6} & Blood & 38.5 & 1.2 & 39.4 & 1.3 & Village & Male (60) & Normal adult \\
\hline & Urine & 9.5 & 1.0 & 9.9 & 0.8 & & & \\
\hline \multirow[t]{2}{*}{7} & Blood & 56.0 & 1.4 & 58.0 & 1.5 & City & Male (50) & Normal adult \\
\hline & Urine & 17.0 & 1.2 & 18.0 & 1.1 & & & \\
\hline \multirow[t]{2}{*}{8} & Blood & 33.5 & 1.8 & 32.8 & 1.6 & Village & Female (40) & Normal adult \\
\hline & Urine & 8.6 & 0.8 & 8.5 & 0.9 & & & \\
\hline \multirow[t]{2}{*}{9} & Blood & 23.5 & 1.7 & 25.0 & 1.5 & City & Female (2) & Convulsion patient \\
\hline & Urine & 5.8 & 0.9 & 6.8 & 1.0 & & & \\
\hline \multirow[t]{2}{*}{10} & Blood & 78.0 & 1.5 & 79.0 & 1.8 & Village & Female (30) & Convulsion patient \\
\hline & Urine & 31.5 & 1.2 & 35.0 & 1.3 & & & \\
\hline \multirow[t]{2}{*}{11} & Blood & 111.0 & 2.1 & 115.0 & 1.8 & City & Female (25) & Convulsion patient \\
\hline & Urine & 50.0 & 1.3 & 55.0 & 1.1 & & & \\
\hline \multirow[t]{2}{*}{12} & Blood & 152.0 & 2.4 & 156.0 & 2.0 & City & Male (48) & Convulsion patient \\
\hline & Urine & 61.0 & 1.2 & 65.0 & 1.1 & & & \\
\hline \multirow[t]{2}{*}{13} & Blood & 52.0 & 1.8 & 58.0 & 1.9 & City & Male (8) & Hemolytic anemia patient \\
\hline & Urine & 29.0 & 1.0 & 32.0 & 0.8 & & & \\
\hline \multirow[t]{2}{*}{14} & Blood & 67.0 & 1.5 & 69.0 & 1.7 & City & Female (45) & Hemolytic anemia patient \\
\hline & Urine & 36.0 & 1.2 & 38.0 & 0.9 & & & \\
\hline 15 & Blood & 125.0 & 2.3 & 130.0 & 1.8 & City & Male (46) & Hemolytic anemia patient \\
\hline & Urine & 45.0 & 1.3 & 50.0 & 1.2 & & & \\
\hline 16 & Blood & 146.0 & 1.6 & 149.0 & 1.5 & City & Male (15) & Lung cancer patient \\
\hline & Urine & 48.0 & 1.2 & 54.0 & 1.3 & & & \\
\hline 17 & Blood & 115.0 & 1.6 & 117.0 & 1.5 & Village & Female (12) & Lung cancer patient \\
\hline & Urine & 38.3 & 1.2 & 39.5 & 1.1 & & & \\
\hline 18 & Blood & 165.0 & 2.5 & 170.0 & 2.1 & City & Female (55) & Lung cancer patient \\
\hline & Urine & 55.0 & 1.2 & 59.0 & 1.3 & & & \\
\hline 19 & Blood & 173.0 & 2.6 & 175.0 & 2.2 & City & Male (55) & Lung cancer patient \\
\hline & Urine & 64.0 & 1.3 & 68.0 & 1.0 & & & \\
\hline 20 & Blood & 85.0 & 1.5 & 91.0 & 1.7 & City & Female (42) & Traffic constable \\
\hline & Urine & 35.0 & 1.1 & 39.0 & 1.2 & & & \\
\hline 21 & Blood & 103.0 & 1.9 & 110.0 & 1.8 & City & Male (45) & Traffic constable \\
\hline & Urine & 50.0 & 1.2 & 55.0 & 0.8 & & & \\
\hline
\end{tabular}


Table 6

Determination of lead(II) and lead(IV) speciation in mixtures

\begin{tabular}{|c|c|c|c|c|c|c|c|}
\hline \multirow[t]{2}{*}{ Serial No. } & \multirow[t]{2}{*}{$\mathrm{Pb}(\mathrm{II}): \mathrm{Pb}(\mathrm{IV})$} & \multicolumn{2}{|c|}{$\begin{array}{l}\mathrm{Pb} \text {, taken } \\
\left(\mathrm{mg} \mathrm{l}^{-1}\right)\end{array}$} & \multicolumn{2}{|c|}{$\begin{array}{l}\mathrm{Pb} \text {, found } \\
\left(\mathrm{mg} \mathrm{l}{ }^{-1}\right)\end{array}$} & \multicolumn{2}{|c|}{$\begin{array}{c}\text { Error } \\
\left(\mathrm{mg} \mathrm{l}^{-1}\right)\end{array}$} \\
\hline & & $\mathrm{Pb}(\mathrm{II})$ & $\mathrm{Pb}(\mathrm{IV})$ & $\mathrm{Pb}(\mathrm{II})$ & $\mathrm{Pb}(\mathrm{IV})$ & $\mathrm{Pb}(\mathrm{II})$ & $\mathrm{Pb}(\mathrm{IV})$ \\
\hline 1 & $1: 1$ & 1.00 & 1.00 & 0.99 & 0.98 & 0.01 & 0.02 \\
\hline 2 & $1: 1$ & 1.00 & 1.00 & 1.00 & 1.00 & 0.00 & 0.00 \\
\hline 3 & $1: 1$ & 1.00 & 1.00 & 0.98 & 0.99 & 0.02 & 0.01 \\
\hline \multicolumn{8}{|c|}{ Mean error: $P b(I I)= \pm 0.01, P b(I V)= \pm 0.01, S D: P b(I I)= \pm 0.005, P b(I V)= \pm 0.006$} \\
\hline 1 & $1: 5$ & 1.00 & 5.00 & 0.99 & 4.98 & 0.01 & 0.02 \\
\hline 2 & $1: 5$ & 1.00 & 5.00 & 0.98 & 4.97 & 0.02 & 0.03 \\
\hline 3 & $1: 5$ & 1.00 & 5.00 & 0.98 & 4.98 & 0.02 & 0.02 \\
\hline \multicolumn{8}{|c|}{ Mean error: $P b(I I)= \pm 0.016, P b(I V)= \pm 0.02 S D: P b(I I)= \pm 0.0058, P b(I V)= \pm 0.006$} \\
\hline 1 & $1: 10$ & 1.00 & 10.00 & 0.98 & 9.98 & 0.02 & 0.02 \\
\hline 2 & $1: 10$ & 1.00 & 10.00 & 0.99 & 9.98 & 0.01 & 0.02 \\
\hline 3 & $1: 10$ & 1.00 & 10.00 & 0.98 & 9.97 & 0.02 & 0.03 \\
\hline \multicolumn{8}{|c|}{ Mean error: $P b(I I)= \pm 0.016, P b(I V)= \pm 0.02 S D: P b(I I)= \pm 0.0058, P b(I V)= \pm 0.006$} \\
\hline
\end{tabular}

validity of our method was tested by analysing several Standard Reference Materials, recovery studies and also comparing the results with conventional analysis (AAS).

The abnormally high values for lung cancer and convulsion patients are probably due to the involvement of high lead concentration in air and water. The occurrence of such high lead contents are also reported concerning lung cancer and convulsion patients from some developed countries [33].

Our results showed that the lead concentration in human fluids were varied with age, sex and place. Children are more susceptible than adults (Table 5). Thus, they can develop encephalopathy at lower blood lead levels. Also, the haem synthetic pathway in children is more sensitive to lead. The occurrence of such low lead contents are also reported concerning children from some developed countries [34]. Another important observation is that females are more susceptible than males (Table 5). Such variation of lead concentration are also reported from USA [35]. There are remarkable variation of lead concentration in human fluids were observed between the urban and rural people (Table 5). The abnormally high values for urban people are probably due to involvement of high lead concentrations in atmosphere due to the use of tetramethyl lead in gasoline. As a result normal blood lead values varies between urban and rural people. The occurrence of such variation of lead concentration are also reported concerning urban and rural people from some developed countries [35].

Some controversy exists concerning the evaluation of blood lead levels. An international working group reached a compromise, that a blood level of $60 \mu \mathrm{g}$ per $100 \mathrm{ml}$ should regarded as permissible limit for occupational lead exposure. However, the experts recognized that some manifestations of lead toxicity develop at lower blood lead values, and that children may be more susceptible than adults. Subsequently, the Commission of the European Communities has suggested that the median blood lead level of the general population should not exceed $35 \mu \mathrm{g}$ per $100 \mathrm{ml}$ [36]. Therefore, the U.S. Environmental Protection Agency has proposed that mean blood lead values in children be kept below $15 \mu \mathrm{g}$ per $100 \mathrm{ml}$ and almost below $30 \mu \mathrm{g}$ per $100 \mathrm{ml}$ [10]. The results of blood analyses (for normal persons) by the spectrophotometric method (Table 5) were found to be in excellent agreement with the permissible limit set by EPA.

Determination of lead(II) and lead(IV) speciation in mixtures. Suitable aliquots (1-2 ml) of lead(II + IV) mixtures (preferably 1:1, 1:5, 1:10) were taken in a 25-ml conical flask. A few drops of $6 \mathrm{M} \mathrm{HCl}$ 
and three to four drops of $2.5 \%(\mathrm{w} / \mathrm{v})$ freshly prepared sodium azide solution were added to reduced tetravalent lead and heated on the steam bath for 5-10 $\mathrm{min}$ to remove excess reductant. The contents were cooled at room temperature. The reaction mixture was neutralized with dilute $\mathrm{NH}_{4} \mathrm{OH}$ and transferred quantitatively into a 10-ml volumetric flask. Then the total lead(II + IV) content was determined according to the general procedure with the help of the calibration graph.

An equal aliquot of the above lead (II + IV) mixture was taken in a $25-\mathrm{ml}$ beaker. One $\mathrm{ml}$ of $0.1 \%$ (w/v) tartrate or thiocyanide was added to mask lead(IV) and neutralized with dilute $\mathrm{NH}_{4} \mathrm{OH}$. The content of the beaker was transferred into a 10-ml calibrated flask and its lead(II) content was determined according to the general procedure using tartrate or thiocyanide as a masking agent. The lead concentration was calculated in $\mathrm{mg} \mathrm{l}^{-1}$ or $\mu \mathrm{g}^{-1}$ with the aid of calibration graph. This gives a measure of the lead originally present as lead(II) in the mixture. The value of the lead(IV) concentration was calculated by subtracting the concentration of lead(II) from the corresponding total lead concentration. The results were found to be highly reproducible. The results of a set of determination are given in (Table 6).

\section{Conclusions}

In the present work, a simple, sensitive, selective and inexpensive micellar method with the $\mathrm{Pb}(\mathrm{II})$ dithizone complex was developed for the determination of lead in biological samples. The presence of a micellar system (altered environment) avoids the previous steps of solvent extraction, and reduces the cost and toxicity while enhancing the sensitivity, selectivity and molar absorptivity. The molar absorptivities of the lead-dithizone complex formed in presence of the cationic CTAB surfactants are almost ten-times $3.99 \times 10^{5} 1 \mathrm{~mol}^{-1} \mathrm{~cm}^{-1}$ the value observed in the standard method $\left(1.9 \times 10^{4} 1 \mathrm{~mol}^{-1} \mathrm{~cm}^{-1}\right)$ and the maxima of absorption is shifted by about $20 \mathrm{~nm}$ when compared with standard method, resulting in an increase in the sensitivity of the method. With suitable masking, the reaction can be made highly selective. Lead in biological samples has been determined by pulse polarography, NAA, ICP-AES, ICPMS and AAS. The first four methods are disadvantageous in terms of costs and instruments used in routine analysis. AAS is often lacking in sensitivity and affected by matrix conditions of samples such as salinity. The proposed method using dithizone in the presence of aqueous micellar solutions not only is one of the most sensitive methods for the determination of lead but also is excellent in terms of selectivity and simplicity. Therefore, this method will be successfully applied to the monitoring of trace amounts of lead in environmental, biological and soil samples.

\section{Acknowledgements}

The authors thank Prof. Dr. Tasnim Gul Qazi of CEAC for analyzing the biological samples by AAS. We are also thankful to Dr. Raana Khan of LUMHS Hospital, Hyderabad. for her generous help in supplying biological samples.

\section{References}

[1] G.D. Clayton and F.E. Clayton (eds), Pathy's Industrial Hygiene and Toxicology, 3rd edn, Wiley, New York, 1981, p. 1687.

[2] R.A. Goyer and T.W. Clarkson, in: C.D. Klaassen (ed.), Casarett and Doull's Toxicology: The Basic Science of Poisons, 6th edn, MaC-Millan Publishing Company, New York, 2001, p. 827. 
[3] L.H. Hurney, in: Trace Element Analytical Chemistry in Medicine and Biology etc., P. Pratter and P. Scharmel (eds), Walter de Gruyter, Berlin, Vol. 3, 1984, p. 375.

[4] L.R. Beecks, Analytical Chemistry 58(2) (1986), 975A.

[5] M.M. Key, A.F. Henschel, J. Butter, R.N. Ligo and I.R. Tebershed (eds), Occupational Deseases: A Guide to Their Recognition, U.S. Department of Health, Education and Welfare, U.S. Govt. Printing, Washington DC, June, 1977.

[6] A.K. De, Environmental Chemistry, 3rd edn, New Age International (P) Limited, New Delhi, 1996, p. 263.

[7] J. Fries and H. Getrost, Organic Reagents for Trace Analysis, Merck Darmstadt, 1977, p. 243.

[8] L. Hageman, L. Torma and B.E. Ginther, J. Assoc. Official Anal. Chem. 58 (1975), 990.

[9] B. Kumar, H.B. Singh, M. Katyal and R.L. Sharma, Mikrochim. Acta [Wien] 111 (1991), 79.

[10] EPA (U.S. Environmental Protection Agency), Proposed Guidelines for Carcinogen Risk Assessment, 1999, Office of Research and Development, NCEA-F-0644.

[11] H. Tani, T. Kamidate and H. Watanabe, Anal. Sci. 14 (1998), 875-888.

[12] E. Diaz Garcia and A. Sanz Medel, Talanta 33 (1986), 255-264.

[13] Humaira Khan, M. Jamaluddin Ahmed and M.I. Bhanger, Analytical Sciences 21(5) (2005), 507-512.

[14] L.C. Willemsons, Handbook of Lead Chemicals, Project LC-116, International Lead-Zinc Research Organization, New York, 1986.

[15] M.J. Ahmed and M. Moniruzzaman, Ultra Scientist of Physical Sciences 13(1) (2001), 25.

[16] Ana Lucia D. Comitre and Boaventura F. Reis, Talanta 65 (2005), 846-852.

[17] M.J. Ahmed and Mosaddeque-Al Mamun, Talanta 55 (2001), 43-54.

[18] S.L.C. Ferreira, M.G.M. Andrade, I.P. Lobo and A.C. Costa, Anal. Lett. 24(9) (1991), 1675.

[19] J.M. Pan, Y.S. Chen and H.T. Yan, Chromagenic Reagent and Their Application in Spectrophotometric Analysis, Shanghai Science and Technology Press, Shanghai, 1981, pp. 411-413.

[20] Z.J. Li, Z.Z Zhu, Y.P. Chen, C.G. Xu and J.M. Pan, Talanta 48 (1999), 511-516.

[21] K. Kilian and K. Pyrzynska, Talanta 60 (2003), 669-678.

[22] B.K. Pal and B. Chowdhury, Mikrochim. Acta 11 (1984), 121-125.

[23] N.S. Murcia, E.G. Lundquist, R.O. Russo and D.G Peters, J. Chem. Ed. 67 (1990), 7.

[24] E.B. Sandell, Colorimetric Determination of Traces of Metals, Interscience, New York, 1965, p. 269.

[25] C.B. Ojeda, A. Garcia de Torres, F. Sanchez Rojas and J.M. Cano Pavon, Analyst. 112 (1987), 1499.

[26] I. Nnkatsuka, A. Nashirmura and O. Kunio, Anal. Chim. Acta 304 (1995), 243.

[27] P. Job, Ann. Chim. [Paris] 9 (1928), 113.

[28] J.A. Yoe and A.L. Jones, Ind. Eng. Chem. Anal. Ed. 16 (1944), 11.

[29] S. Mitra (ed.), Sample Preparation Techniques in Analytical Chemistry, Wiley-Interscience, New Jersey, 2003, p. 14.

[30] G.A. Parker, Analytical Chemistry of Molybdenum, Springer-Verlag, Berlin, 1983.

[31] C. Sun, J.Y. Yang and S.R. Tzeng, Analyst 124 (1999), 421.

[32] S. Mitra (ed.), Sample Preparation Techniques in Analytical Chemistry, Wiley Interscience, New Jersey, 2003, pp. 230233.

[33] R.A. Vercruysse, Hazardous Metals in Human Toxicology, Part B, Elsevier, New York, 1984, pp. 153-163.

[34] R.L. Boeckx, Analytical Chemistry 58(2) (1986), 274A-287A.

[35] Federal Register, Occupational Exposure to Lead, Final Standard, U.S. Department of Labor, Occupational Safety and Health Administration, Washington DC., November 14, 1978, p. 52963.

[36] J. Smeets, Ecotoxicological Environmental Safety 2 (1978), 143-150. 


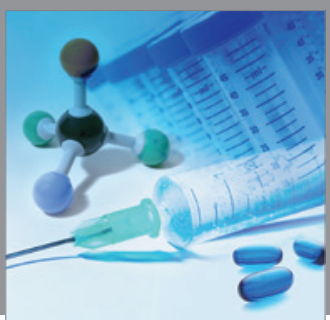

International Journal of

Medicinal Chemistry

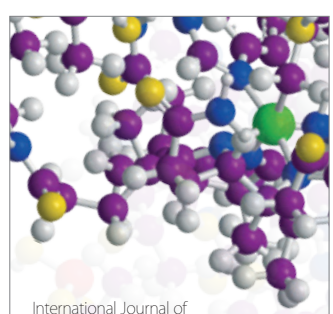

Carbohydrate Chemistry

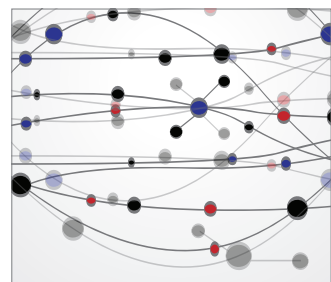

The Scientific World Journal
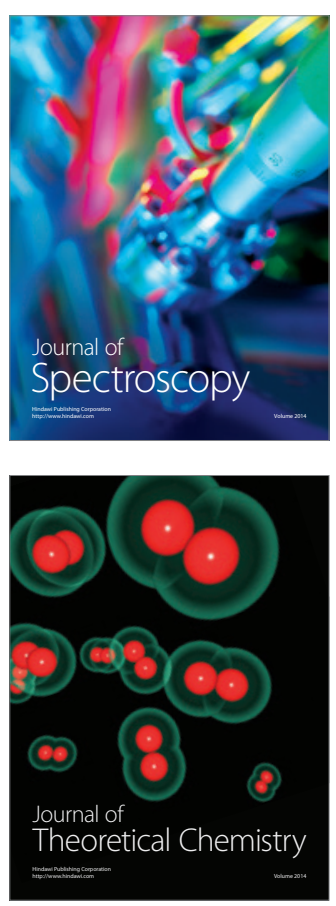
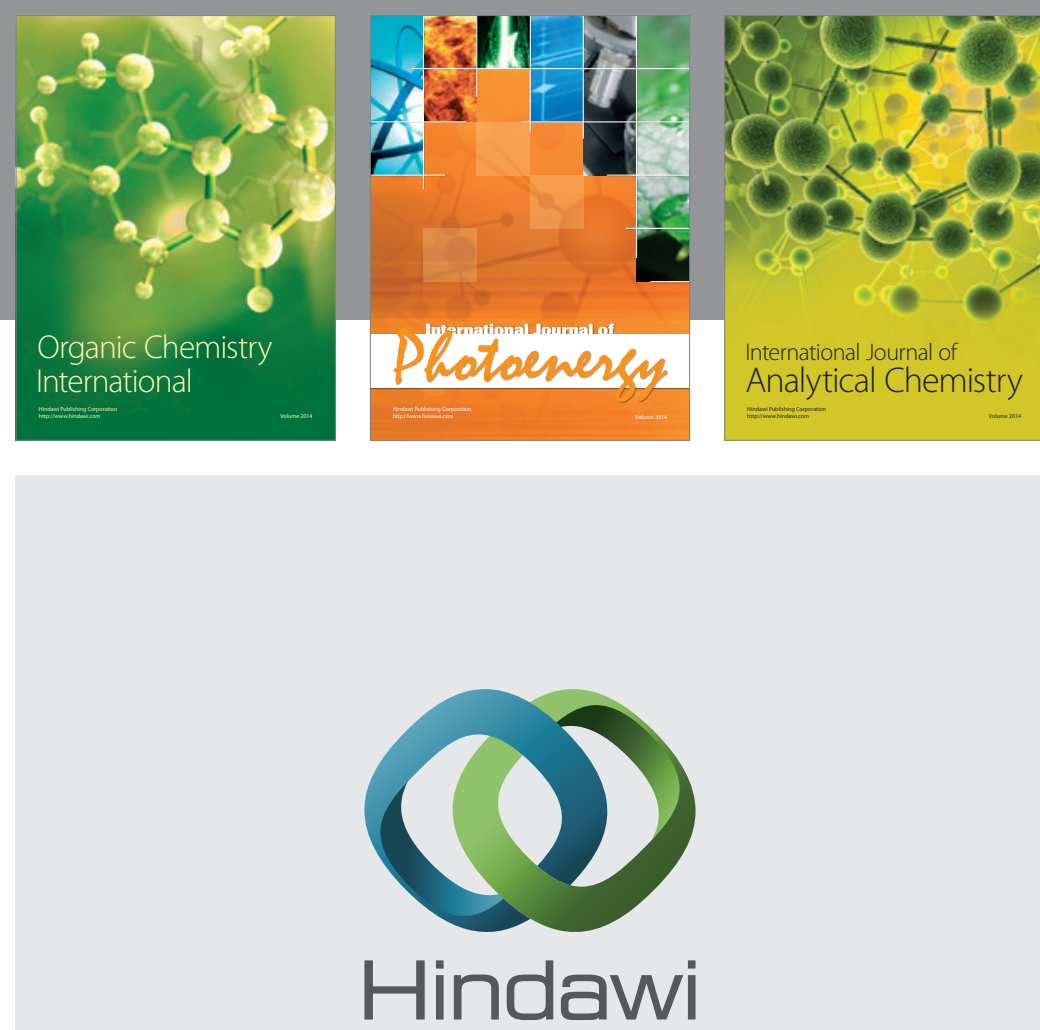

Submit your manuscripts at

http://www.hindawi.com
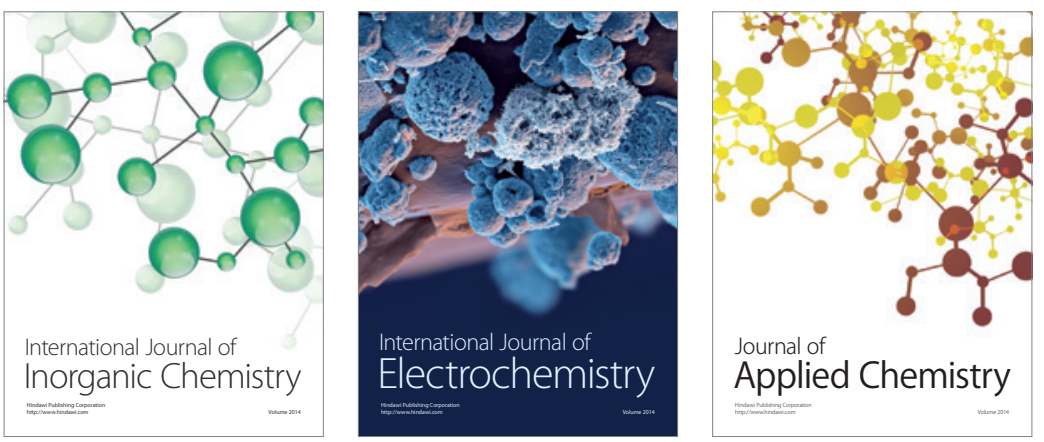

Journal of

Applied Chemistry
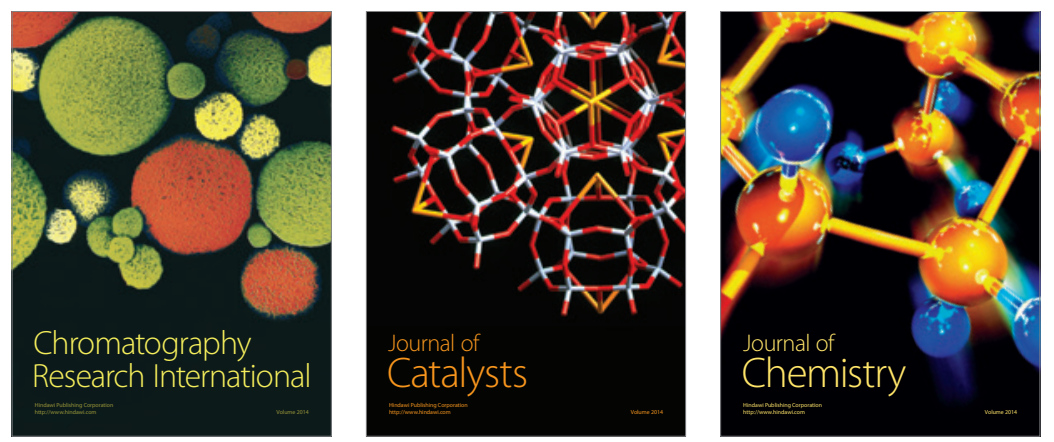
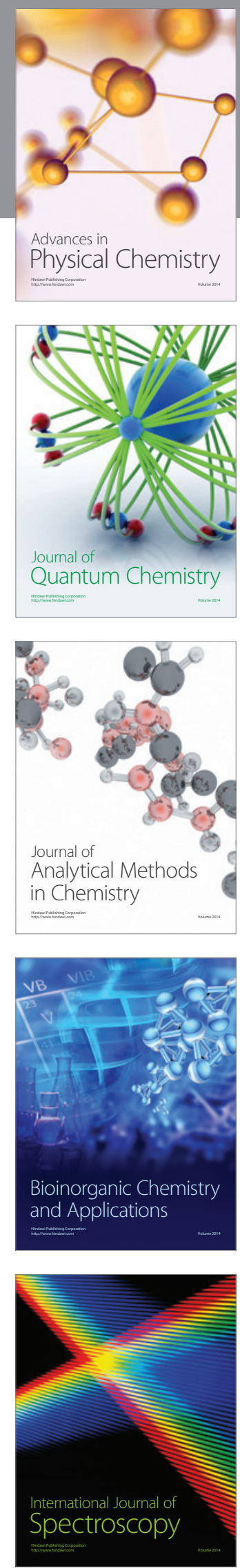